\title{
Politicizing Muslim Mental Health: Toward a Decolonial Framework
}

\author{
Tarek Younis*
}

\begin{abstract}
There is a growing recognition that mental illness should be taken more seriously within Muslim communities. In this are calls to Islamicize psychology or psychologize Islam, whereby the former attempts to adapt contemporary psychological practices for Muslims while the latter endeavors to indigenize and establish a psychology rooted firmly in Islamic traditions. An extensive body of work demonstrates how Muslims are uniquely politicized across the Global North as the common "Other" in nationalist discourse. There is a need to underscore the significance of the political which underpins the relationship between the concepts of 'Muslim' and 'mental health'. The political domain will be explored by addressing three paradigms and their particular relationship to Muslim mental health: neoliberalism, nationalism, and securitization. I argue that Muslim mental health, irrespective of approach or discipline, is unique in its ability to cultivate loyal and productive subjects of the nation-state. Emerging Muslim mental health models may succeed in their stated objective-alleviate suffering or raise God consciousness-but they do not address the political dimension underlying mental health practice itself. I argue that a decolonial movement must remain in constant resistance with dominant ideological paradigms. Furthermore, it must be rooted in an interdisciplinary praxis based on communal trust and shared responsibility, and ensure Muslim suffering is neither commodified nor rationalized from its causes.
\end{abstract}

\section{Keywords \\ Islamophobia $\bullet$ politics $\bullet$ epistemology $\bullet$ mental health $\bullet$ Muslim}

\section{Introduction}

The burden of mental health disorders is said to have reached $13 \%$ of the world's population (Tomlinson, 2013). This has provoked a surge of global mental health initiatives, not least the World Health Organization's Mental Health Act plan (World Health Organization, 2013). While some have critically evaluated the moral panic associated with this alleged "epidemic of mental disorders" (Rose, 2018), the population's mental health vulnerability has increasingly become the

*Middlesex University, t.younis@mdx.ac.uk
(D) https://orcid.org/0000-0002-0747-8782

Correspondence concerning this article should be addressed to Tarek Younis Department of Psychology Middlesex University, Hendon, NW4 4BT, United Kingdom.

$$
\text { doi: } 10.3998 / \text { jmmh.143 }
$$

Conflicts of interest:

The author has no conflicts of interest to disclose. 
concern of governments (Furedi, 2003). So, too, is Muslim Mental Health (MMH) on the rise (Altalib et al., 2019). Indeed, there is growing recognition that mental illness should be taken more seriously within Muslim communities, a viewpoint driven by grassroot Muslim organizations and the health industry alike. The purpose of this article is not to explore why mental health is gaining traction within Muslim communities, nor is it an analysis of how Muslims fit 'Islam' within contemporary psychological practices. Instead, this article will underscore the significance of the politics which underpins the relationship between the concepts of 'Muslim' and 'mental health'. It will argue the necessity to consider a decolonial Muslim mental health as a praxis that is in constant resistance with reigning ideological paradigms (Hallaq, 2019; Seedat, 2020).

In his writings on liberation psychology, Martín-Baró (1996) asserted the need for professionals in psychology disciplines to critically examine their roles in serving the status quo. Accordingly, Hallaq (2014, p. 68) writes that "the political is an all-encompassing, pervasive phenomenon that intrudes upon all fields, upon existence itself." The retreat from the political in mental health is not unique to Muslims. Lasch (2018) argued that Western culture's fixation on self-actualization and self-awareness in fact clouds a wholesale retreat from the political. In turn, Seedat (2020, p. 6) identifies liberation as indispensable for a decolonial movement in Islamic psychology, "comprehending the intersections between power, structure, and the formation of subjects and subjectivities."

Drawing upon a range of interdisciplinary sources, I argue the MMH field is unique in its youthfulness and its ability to serve those in power. This article attempts to identify the socio-political environment which $\mathrm{MMH}$ in the Global North must navigate in practice. In doing so, this article will outline the limitations in the drive for 'Islamic models of psychology' or 'Muslim-sensitive interventions' regardless of discipline or approach ${ }^{1}$. The significance of the political will be explored by addressing three contemporary movements and their particular relationship to Muslim mental health: neoliberalism, nationalism, and securitization.

\section{Being Muslim: Beyond Religious Identity}

An understanding of power and structure first requires a consideration of what 'Muslim' means in the Global North. This conundrum often sidesteps the vast diversity of ethnicities, histories, and (non-)practices of Muslims and challenges the notion of speaking about Muslims as a monolith (Younis \& Hassan, 2018b). However, for the purpose of underlining the significance of the political in MMH, I will be relating to 'Muslim' as a significant political categorization, beyond self-identification (Jenkins, 2014). In other words, individuals and groups are racialized as Muslims inasmuch as they proclaim to identify as such. The political dimension of 'being Muslim in the West' is especially salient when considering the complexity of Islamophobia.

Kundnani (2017) succinctly summarizes the various ways Islamophobia has been viewed as an object of analysis, both personal and structural. For the personal, Islamophobia often connotes explicit expressions of individual hostility, rendering it a cognitive distortion rather than a system of meaning (Skrentny, 2008, p. 65). This framing of Islamophobia is a key feature of the United Kingdom (UK) Conservative party's talk of 'anti-Muslim racism', which sees Islamophobia exclusively emanating from fringe 'hate groups' on the margins of society (Fekete, 2018). A structural understanding of Islamophobia, on the other hand, sees it as culturally and politically reproduced by state structures and elite interests, who frame Muslims and Islam as foreign (or regressive) entities within a liberal nation-state. In this latter definition, Islamophobia fits within a logic orbiting around the ethnocentrism of Western nationalism, hence the significance of racialization (Valluvan, 2019). The nation necessitates this Muslim

1. Psychiatry, psychology, and counseling will hereon be referred to as 'psy disciplines.' 
"Other"-referenced in racial and civilizational terms-to consolidate its political boundaries of belonging (Goldberg, 2008).

The concept of racialization explains the Brexit campaign's use of imagery depicting long lines of Muslim-like people seeking entry into Europe, counter-terrorism referrals made toward Muslims growing beards, and the increased sensitivity towards White converts as potential security threats as their conversion to Islam may be viewed as the ultimate rejection of the ethnonationalist logic embedded within citizenship (Younis \& Hassan, 2017). In all these cases, racialization is at heart of the process, for all these bodies and behaviors embody a social conflict (the "War on Terror", the "non-integration" of Muslims) in public consciousness. But Islam also plays a key in this respect. Islam has long played a political role within European history, positioned as the 'Other' outside - and thereby in the boundary-making of - 'Western civilization'. This is certainly the case since the Enlightenment, where thinkers such as Hegel and Voltaire viewed Islam as a quintessential force of fanaticism in juxtaposition to liberal Western values (Toscano, 2017). The West's historical relationship with Islam feeds into the present conditions of Muslims.

If Muslim agency is perceived to harbor the potential of non-belonging-and therefore is a threat - the effect of Islamophobia can be seen as the depoliticization of Muslim agency ${ }^{2}$. This depoliticization of Muslim subjectivity frames this article's discussion of 'being Muslim' in modern liberal nation-states and situates the need to politicize Muslim mental health. When thinking of 'Muslim' as situated within space and time, and not simply another ethnic or religious identity, therein lies the need to marry the segregated disciplines of psychology with other social sciences.

\section{The State of Discourse on Muslim Mental Health}

The nature of the relationship between Islam and Western psychology has been a long-standing point of interrogation. Malik Badri is one of the most recognized names in this discussion, his work now spanning decades from a critique of Western psychoanalysis in the 1960s (Khan, 2015) through a recent translation of al-Balkhi (b. 849 CE) whom Badri considers a prototypical Muslim psychologist (Badri, 2016). This latest book can be seen as a venture to demonstrate how contemporary psychological approaches (such as cognitive-behavioral therapy) can be found in the works of traditional Muslim scholars. If the $20^{\text {th }}$ century has produced two distinct approaches in the modernization of mental health for Muslims, distinguished in attempts to Islamicize psychology or psychologize Islam, Badri's approach may be viewed in the latter. In other words, Badri's translation can be viewed within a tradition of retrospectively tracing contemporary psychological practices in Islamic history. The interest in this article however will be the former: the Islamicization of psychology.

The Islamicization of psychology belongs to a larger Islamicization of knowledge (IOK) project (Long, 2014). According to Long's history of the phenomenon, the IOK was a reaction within colonial Muslim-majority lands who adhered to the secular programs of their colonizers, despite their newly found independence. The IOK was an attempt to indigenize knowledge and establish a psychology rooted firmly in Islamic psychology. Among Muslim nations, Long explains how the postcolonial projects of indigenizing psychology took the form of either reworking Western psychology (revisionist) or elaborating a unique Islamic position supposedly premised in classical Islamic traditions (classical). As Long (2014, p.17) further explains however, revisionist movements do little to address the underlying ideological commitments of

2. Unless Muslims explicitly 'politicize' themselves according to state/corporate interests. 
Western psychology, which is "saturated in a secular metatheory that cannot accommodate the Islamic worldview, any attempted revision must remain, in spirit, no different from the original articulation."

Meanwhile, classical elaborations of a traditional 'psycho-spirituality' sidestep their suitability for-or indeed erasure of - the modern world. According to Long (2014), the classical position appears to be often upheld by non-psychologist theologians who dismiss how some contemporary Muslim consciousness (such as the Arab uprisings of 2011) is not entirely turning toward the past, but rather is attempting to construct a new future given their current conditions. In doing so, those advocating a classical approach may dismiss the significance of the current economic and political conditions of Muslims. This is especially significant for the purpose of this article. Uncritical movements towards a 'psychologizing Islam' forecloses the structural and institutional powers which give preference to certain mental health interventions over others.

On the ground, there is a growing institutional enthusiasm to improve mental health services and access among Muslims in the Global North. As Kaplick and Skinner (2017) summarize, the various Associations and Congresses (such as the American Psychological Association and the Royal College of Psychiatrists) have recognized the growing importance of spirituality and have designated special groups as a result. Here it is important to address Kaplick and Skinner's (2017) distinction between Muslim mental health and Islam and psychology. The authors relate the former to mental health research focusing on Muslims writ large, and the latter to various epistemological questions regarding Islam and Western psychology. This article will insist on $\mathrm{MMH}$ as an umbrella term because, inevitably, both are intended for Muslims. The performance of Muslim mental health underlines the discussion of the political.

\section{Politicize to Decolonize Mental Health}

This article follows in the spirit of other decolonial engagements with Islamic psychology. Bulhan (2015) provides a wider history of meta-coloniality and its lasting and contemporary impact on psychological sciences. In particular, he relates the colonial enterprise with which the psy disciplines belie their stated objectives of wellbeing. The Eurocentrism of Western psychology is not simply a question of epistemology (or cultural sensitivity), but that Eurocentrism was inherent within the field as a tool for exploitation, social control, and global expansion (Bulhan, 2015). Similarly, Mohr (2019) and Ali-Faisal (2020) relate to the possibility of an emerging Islamic liberation psychology. Both authors synchronically call for dialogical engagement with power structures, arguing for anti-capitalist and anti-imperialist resistance within Islamic psychological theory and practice. Most pertinently for this article, Seedat (2020) provides a comprehensive overview of the potential of Islamic psychology as a decolonial paradigm. Seedat (2020) underlines the decolonial impulse of the original Islamic psychology movements, which has since been marred by issues of definitions, theories, and analysis. Ultimately, he argues "literature on Islam and psychology does not engage explicitly with the lurking influences of coloniality of power, knowledge, and being on the formation of hegemonic and counter-hegemonic psychologies" (Seedat, 2020, p. 3).

Why is there a need to politicize $\mathrm{MMH}$ if decoloniality is the predominant frame of critique? Perhaps the best response to such questioning was given by Cushman (1996, p. 248), who argues that because therapists "believe that the patient's mental "health" will automatically translate into a correct political position, they are not contributing to the status quo". In other words, whether therapists are aware or not, the mental health paradigm, or what Cloud (1997) calls the language of a 'therapeutic ethos', has a political function in modern society. Parker 
(2007) has expanded on the politics underlying psychological discourse, outlining how psychologists reify the political 'status quo' through their own ideological commitment to 'neutrality'.

Some may construe a call to re-politicize Muslim mental health within a wider project of political Islam (or its pejorative term, Islamism). This reflects a particularly Western trend of delineating between the religious/private and the secular/public more generally, but moreover, the acute orientalist apprehension toward Islam as a comprehensive social project which extends itself outside the domain of religious rituals (Sayyid, 2014). While this has been the subject of widespread discussion, for the sake of stating a position, my claim in this article is that both 'Muslims' as well as 'mental health' are both necessarily political constructs which cannot simply be reduced to their alleged religious or scientific affiliations, respectively. Thus, the need to politicize Muslim mental health is not one which endows MMH with a political frame, but rather uncovers the political within it. Below is a discussion of three political developments-neoliberalism, nationalism, and a growing securitization industry, which normative $\mathrm{MMH}$ discourses must address. Notably, these strands are not mutually exclusive but weave a tapestry that is larger than the sum of its parts.

\section{Neoliberalism and the Management of Resilience}

Modern psychology is an artifact of liberal-capitalist ideology and neoliberalism represents the evolution of this hegemony in a globalized age (Bell \& Green, 2016; Cushman, 1996) ${ }^{3}$. Neoliberalism is rightly criticized as a catch-all phrase for social ills in contemporary times (Bell \& Green, 2016; see Rose, 2018 for a discussion of neoliberalism and psychiatry). The American and British shift toward a neoliberal political economy exemplifies the economic evolution of Keynesian capitalism. As such, one may very well argue that capitalism is sufficient as an explanatory term to frame the development of psychology; indeed, there is a wealth of writing exploring the relationship between capitalism and wellbeing (Cloud, 1997; Cushman, 1996; Davies, 2016; Furedi, 2003). Phillip Cushman (1996), for example, gives a profound, historical account how self-actualization is itself a product of an individualized, 'empty self' ushered by modern capitalist societies.

In this article, the choice of neoliberalism over capitalism however is due to its contemporary association with privatization and austerity policies which are closely linked to the content and practice of mental health. But rather than discuss neoliberalism in broad terms and reify its intangible danger on society, this section will home in on a singular concept tying together neoliberal governance, mental health practice and Western Muslims: Resilience. Resilience is not a novel concept nor is the history of the concept confined to individual wellbeing (Joseph, 2018). That being said, its current neoliberal iteration is significant given its mass appeal. The central concern with resilience, in its neoliberal iteration, is the overwhelming responsibilization of individuals for their own distress to the exclusion of political and economic factors.

Joseph (2018) outlines a detailed analysis of resilience as a concept especially in Anglo-Saxon nation-states. From a Foucauldian lens, Joseph explains the emergence of resilience in policy as it fits within a logic of neoliberal governmentality. Increasingly, individuals and communities are responsibilized to 'protect themselves' from future ills, decentralizing the role of the government in providing political solutions (de Vos, 2012). As Bottrell (2013) further explains, the notion of

3. Neoliberalism is difficult to define theoretically as it encompasses a wide range of social, political, and economic movements. That being said, my understanding of neoliberalism will draw upon Saad-Filho and Johnston's (2005) discussion of the term who relate to its most basic feature: The global elite's systematic use of state power to develop a global economic system of minority power. Neoliberalism cannot be disassociated from either globalization or imperialism. 
resilience and responsibility are not to be taken in isolation but belong within wider structural inequities especially caused by austerity. A neoliberal ideology, as a political attitude translated within policy interventions, penalizes individuals for their own shortcomings. Individuals are increasingly made responsible for their mental health, poverty, and family issues, while public services simultaneously see their funding slashed or privatized.

Through neoliberal governance, the state positions the ideal wellbeing and economic status of the White middle class as the default standing to which social mobility should be sought. This makes responsible all (but especially non-White) populations to achieve this status, and pathologizes deviations within a framework of resilience. Neoliberal governance thus is not only a means of managing and controlling the disadvantaged, but equally a technique of protecting privilege and ensuring those in power remain the designers and arbiters of what constitutes wellbeing. Furthermore, as austerity further disintegrates public services across the United States (US) and UK, disproportionately impacting those on the margins of society, mental health is positioned as a panacea to the suffering this causes. Ideally, however, the cheapest option sees to it that people are unaffected by economic and political turmoil-hence the significance of resilience.

This is not to say that resilience is itself unnecessary or without benefit, but rather that that the performance of 'resilience building' in the US and UK cannot be abstracted from its political privilege. Here one can observe two manners in which resilience figures into MMH. The first deals broadly with maintaining ideal, productive, racialized citizenship, and the second narrowly on the War on Terror's positioning of Muslims as a 'risk' community. As for the latter and its relation to $\mathrm{MMH}$, this will be further elaborated upon in the securitization section below. Suffice to say, as Joseph (2018) surmises, counterterrorism has played a central role in invigorating discussions on resilience in both American and British policy. Insofar as the threat of terrorism is racialized to Muslims, the impetus for Muslims to develop 'resilience' takes a unique moral and political salience. This raises concern for MMH's rhetorical usage of resilience in this regard, even if not counter-terrorism is not explicitly outlined as an objective.

But insofar as the neoliberalization of $\mathrm{MMH}$ is concerned, there is a wider ideological drive to embody the 'productive Muslim', resilient to psychological states which render us the opposite. William Barylo (2016) provides an enlightening account of this, highlighting how Muslims across the Global North have propagated models which seamlessly merge spirituality with productivity under the auspices of neoliberal thought. If we take Mohammad Faris's (2016) outline of the Productive Muslim, the author reduces capitalism to "purpose-less" productivity (i.e., hedonism) while simultaneously reproducing a neoliberal logic valuing individual resilience above all else. This is most salient, for example, when he argues that "along the way, the ummah [Muslim community] plunged into un-productivity-not because of colonization or other external factors as we normally blame, but-because of a set of misconceptions that seeped into the ummah's subconscious" (Faris, 2016, pg. 60). Herein lies the two revealing factors of neoliberalism's contemporary logic. First, it accentuates the individual in explicit exclusion to other factors - in Faris's quote, colonial legacy. Second, it draws explicit attention to the collective psyche as the primary locus of intervention-in Faris's quote, the "subconscious" writ large.

With liberal-capitalism as the foundation of contemporary psychological practices, Muslim mental health demonstrates a strong potential of reifying this hegemony with a theocentric-individualism (Long, 2014, p. 16). But make no mistake, the drive towards productivity is not limited to Muslims. Indeed, within a rising tide of political discourse which starkly differentiates between productive and unproductive non-White citizens, Muslims are also subject to tendencies of promoting themselves as prima facie citizens of production. In other words, the 
desire to appear productive takes on a special burden for Muslims across nationalist projects in the Global North which are more explicitly differentiating 'worthy' outsiders from the rest (Valluvan, 2019). It is more than likely that a MMH endeavor seeking to develop 'resilience' does so with best of intentions. Nonetheless, under the burgeoning neoliberal forms of governance, I contend $\mathrm{MMH}$ has three components to resilience which it must navigate: 1) austerity and divestment of community services, 2) the general increased responsibilization for individuals to be 'risk-oriented' and protect themselves from future illness and 3) the specific construction of Muslims as a 'risky' community both in terms of their national identities but also their psychological wellbeing.

\section{Nationalism and the Management of Belonging}

The significance of being racialized as 'Muslim' in the Global North cannot be understated. Today, Western nation-states are experiencing an unprecedented degree of uncertainty through globalization and demolition of social infrastructure (Bauman, 2013). Amid economic crises, neoliberal policies exacerbate the escalating disparity between rich and poor. Endless wars driven by profiteering abroad have resulted in social and political upheavals across the Global North (Bertho, 2018). Throughout this turmoil, political elites draw upon a long-standing history which sees 'Islam' outside the fold of the 'West', producing moral panics associated with backwardness, threat and disobedience - the embodiment of a 'looming death' of European civilization (Goldberg, 2008).

The Muslim is thus not simply just another 'Other' in all this turmoil, akin to other ethnic minorities. Rather, as many have argued, the maintenance national cohesion in these uncertain times ("who we are") requires a perpetual performance of political boundary-making in explicit distinction to Muslims ("who we are not"; Valluvan, 2019). As Norton (2013) explains, just as a recession exacerbated a national anxiety which provoked the 'Jewish Question' in pre-World War II Germany, today's national anxiety is the 'Muslim Question.' Muslims today must continuously perform their national identity to prove their belongingness and maintain their 'outsider insider' status. When the UK government illegally rendered Shamima Begum stateless for her choice (at the age of 15) to join ISIS, it sent a clear, disciplinary message to British Muslims: they hold a lower-tier, precarious citizenship (Johnson \& Fernandez, 2019).

Today nationalism may figure more explicitly into mental health through the psychologization of counter-violent extremism practices (discussed in the next section), but it is important to note that nationalism has always factored into the psy disciplines insofar as all technologies of the self are necessarily subordinate to the nation-state (Nolan Jr, 1998; Rose, 1999). The discussion here will focus particularly on nationalism's relation to 'identity'. Much of what constitutes social identity literature among Muslims across the Global Northespecially following 9/11-follows a similar thread: Contemporary political discourse views national-religious integration as integral to Muslim identity development (Younis \& Hassan, 2018a). Though, again, the focus here is on the UK, there are nationalist projects across the Global North which espouse a similar political agenda (Fekete, 2018). For example, Denmark has recently introduced the 'ghetto policy' which demarcates neighborhoods with largely 'non-Western'-a term the Danish government explicitly reference-inhabitants from Danish ones (Hassani, 2020). Minorities living in these designated 'ghetto zones' are subject to harsher criminal sentences than their white-majority counterparts in a two-tier justice system. Excavating the logic of this strategy reveals the fabricated moral panic concerning the "parallel societies" of Muslims. 
Back in the UK, the contemporary stroke of nationalism in government strategies following the alleged death of multiculturalism is clear. In 2015, for example, David Cameron explicitly framed the reason why 'young Muslims are drawn' to Islamist extremism as a function of Britain's weakened collective identity (Klug, 2015). Cameron especially emphasized the need for 'muscular liberalism'. This prompted government actions such as Communities Secretary Eric Pickles sending out letters to British mosques with the following line: "There is a need to lay out more clearly than ever before what being a British Muslim means today: Proud of your faith and proud of your country" (Pickles 2015, quoted in Klug, 2015, pg. 75). Thereupon, the British government introduced 'Fundamental British Values' (FBV) within educational curriculums to 'prevent extremism', much to the overwhelming dismay of teachers and families (Open Society Justice Initiative, 2016). Adib-Mogghaddam calls this psycho-nationalism, which she explains "is a source of identity for all those who are considered a part of the in-group of "imagined community', while it fosters intolerance and hate toward those who do not belong to it" (2017, p. 14). Today these nationalist performances pivot around counter-extremism, a strategy which has organically absorbed the long-standing integration debate of Muslims. The logic is crude and essentializes political violence within an elusive and paper-thin performance of social identity theory; if a Muslim celebrates their Britishness, it is alleged, they could never turn against Britain.

The intersection between national interest and the psy disciplines is nothing new (see Rose, 1999 for an overview). Wartime German psychiatry is a prototypical example in this regard for example, where "mentally ill individuals were assessed only with reference to their constantly redefined usefulness or burdensomeness to the state and society" (Schmiedebach \& Priebe, 2004, p. 462). In the United States, American psychiatrists argued Black men needed psychiatric interventions following their interest in figures such as Malcolm X, for this threatened both their own mental health as well as American social order (Metzl, 2011, p. 71). Today, we see Extremism Risk Guidance Framework-a counter-extremism measure privileging nationalism and white innocence-is embedded within mental health settings (Younis \& Jadhav, 2020). Through counter violent extremism (CVE) discourse, as I will outline in the next section, nationalism has become thoroughly psychologized for the modern age.

For Muslims, the most glaring example of nationalism's significance is how 'wellbeing' is postulated as integrated national-religious identity. Herein lies one of the various permutations of social identity theory, which reifies a political dynamic that Muslim 'identities' are in perpetual state of psychic conflict (Younis \& Hassan, 2018a). A Muslim's refusal or rejection of national identification is psychologized within a framework which sees this act as an abnormal developmental trajectory, rather than an independent act (Younis, 2020). Thus, MMH is ideally positioned to promote a model of 'wellbeing' in which national identity is viewed as an integral factor. Beyond the recognition of how normality is ideologically constructed then (Frances, 2013), more serious attention must be devoted to how nationalism figures into the particular construction of Muslim normality.

\section{Securitization and the Management of Risk}

Bridging neatly from neoliberalism and nationalism, the security sector flourishes at their intersection. The significance of mental health in national security concerns can be gleamed by the manner in which counterterrorism strategies have evolved. In the 2000s across US and Europe, policies were introduced which saw the reformation of Western Muslim 'hearts and minds' as integral in the War on Terror (Kundnani, 2014). In the UK, this eventually developed into a national CVE strategy, Prevent, which eschewed the winning of 'hearts' for the surveillance of 
'minds', monitoring precriminal thoughts and behaviors (Younis, 2020). Since 2015, Prevent has made it a statutory duty for all public bodies to have due regard in identifying individuals they suspect are vulnerable to becoming/supporting terrorists in the future (Sabir, 2017). As explained previously, the state perceives Western Muslims to embody the potential of the anticitizen (Sayyid, 2014). CVE thus attempts to identify and index individuals between citizens and anticitizens as a preventative measure. In doing so, the state's counter-terrorism strategy reproduces the dynamic of the 'good/bad Muslim' binary in practice, which inevitably reifies their racialization as well (Kundnani, 2017, p. 44).

Incidence of political violence immediately produces a search for the holy grail of explanatory models, a unified, psycho-social model of radicalization (Silke, 1998). Such a search is inevitable; modernity is psychologized whereby all social and political phenomena are viewed within this therapeutic lens (Cloud, 1997). This is not to say that all human events are inevitably subsumed under psychology for deconstruction. Arguably, the management of political subjectivity has remained a central thrust of the nation-state ever since psychological tools and techniques were developed (Rose, 1999). Mental health professionals thus have had a significant professional role, not simply in the management of subjectivity, but inadvertently in the cultivation of a culture of vulnerability (Furedi, 2003). While there may be a rhetorical recognition of how social and political factors (e.g. illegal wars) drive ills such as political violence, the vast majority of state strategies are built around the individual qua individual. This privileges thus the role of mental health professionals to monitor and manage individual risk.

Psychological tools are thus readily deployed in public bodies without evidentiary basis of their validity and concealed in the interest of national security (Bhui, 2016; Younis, 2020). There are several important ways in which $\mathrm{MMH}$ figures into the growing securitization industry. First, Muslim mental health professionals are increasingly offered involvement opportunities in counter-terrorism strategies at all levels, including promoting mental health resilience within communities, providing risk assessments at the local level, and consulting towards the improvement of CVE policies nationally. Indeed, I discovered during my fieldwork on the Prevent policy a number of Muslim psychiatrists and psychologists who have already joined CVE initiatives (be it local or national), though none had a particular background in political violence. Given the psychologization of political violence, as well as the strategic benefit in having 'insiders' from the community involved in highly racialized conflicts, we can expect national security openings for MMH professionals to grow. This undoubtedly raises the question if a MMH professional's cooperation with the security apparatus - even if well-intended - compromises their practice as 'safe' within the Muslim community. Unfortunately, this issue remains overlooked in research, though there is a growing appreciation of how securitization negatively impacts intra-community relations (Abbas, 2018).

Second, austerity has cut government spending on specialized services across the board, including mental health. In turn, a public competition for governmental funding has ensued, vying for support for culture and illness-specific services. At the same time, counterterrorism has incentivized mental health treatment under the guise of national security. For example, British healthcare staff may flag 'radicalization' to fast-track their patient toward mental health services, rather than stalling their treatment on a waiting list (Heath-Kelly \& Strausz, 2018). To extrapolate this logic even further, we also see an increased level of funding for services associated with counter-extremism in public funding. For example, the Mayor of London publicized a sizeable CVE investment of $£ 400,000$, whose understanding of drivers towards extremism includes mental health (Mayor of London, 2017). As such, the inherent competitiveness in funding allocation, exacerbated by austerity, may incentivize well-meaning professionals to frame Muslim mental health concerns under counterterrorism. 
Third, securitization may very well impact psychotherapy practice as a whole. In Rizq's (2017, p. 353) concluding remarks following her insightful commentary on the hazard of introducing pre-crime into psychotherapy, she asks, "what counts as therapy where counter-radicalization discourses pre-empt and colonize the very spaces of free speech and imaginative thinking on which psychotherapy depends?" Once the logic of national security enters therapy, it invades the intersubjective space. To make this argument, the example of trauma will be drawn. We know in the US that Black youth experience a heightened state of anxiety when dealing with the police, and that police encounters are often traumatic (Bor et al., 2018). For Muslims, there is an emerging appreciation for the anxiety associated with authorities as well (Cherney \& Murphy, 2016). Potentially, a Muslim mental health professional will deal with the trauma of their client involving medication, therapy, etc. But what if the client, in their negative experiences of state repression, maintains a hostile attitude toward government repression such as egregious police practices? From what can be gleamed from above, this immediately falls into a gaze which sees the Muslim as the potential anti-citizen and a threat. The adolescent's anger is then no longer a free expression of their political agency but a potential security threat to be treated with mental health support and state-approved ideological mentoring.

Fourth, and perhaps most significantly, is the element of trust. Mistrust is well recognized as a barrier for mental health access for those with unfavorable experiences with authority, like refugees (Colucci et al., 2015). This is especially significant in matters of confidentiality, upon which the therapeutic alliance depends. In the UK, a recent admission by the government makes it absolutely clear that a client's consent is not needed for a radicalization referral (Grierson, 2020). This is critical and cannot be understated: If Muslims become aware that a CVE referral breaches the sanctity of patient/professional relationship - and in my experience, few are aware of this-then we can expect a stern impact on public mental health access. This is not conjecture though it is anecdotal; ever since I began my research on CVE (see e.g. Younis \& Jadhav, 2020), Muslim young adults have admitted withholding seeking mental health support out of fear of securitized breaches of confidentiality, irrespective if the therapist is Muslim or not.

\section{Toward a Decolonial Framework}

In the above, I posited three arguments on why and how MMH presents a commanding potential of ensuring Muslims remain productive and loyal citizens. $\mathrm{MMH}$ activities can thus be seen as inevitably embedded within reigning paradigms of capitalism and nationalism. Herein lies the significance of psy technologies, alongside others (legal, educational, etc), which ensures there is a codification, classification and remedy for the complications modernity itself has wrought (Hallaq, 2014). To this, the distinction between Foucault's processes of being disciplined through state apparatuses and surveillance on the one hand, and processes of self-discipline along state interests on the other, remains elusive (De Vos, 2012). Jan de Vos (2012) suggests that the process of psychologization provides an explanatory bridge between state discipline and self-discipline. This raises then the question if therapeutic rhetoric itself shapes and constrains Muslim subjectivity according to the interests of power.

The purpose of this article has been to reflect then on the future of MMH. Current tendencies in research either focus on Islamicizing contemporary psychological practices or psychologizing traditional Islamic scholarship to treat Muslim distress. My argument is not that these efforts are obsolete; quite the contrary, some have shown to be beneficial for Muslim clients. Mir's (2019) Muslim-adapted therapy for depression based on behavioral activation is a positive example in this respect. However, even if such interventions succeed in their stated objective (e.g., alleviate suffering and/or raise God consciousness) they do not address the conditions of 
suffering nor the political dimensions underlying mental health practice. In other words, all such adaptations still operate according to and within the nation-state's parameters, as discussed throughout this article. An Islamicization of Psychology cannot occur without decolonizing the practices of mental health first, nor can decoloniality be separated from the political and material conditions in which mental health practices are embedded.

This last point does not receive enough critical attention in Muslim mental health research. For example, in looking toward the future of Islamic psychology, Haque and colleagues (2016) observe the need to deepen our understanding of Islamic theology as it relates to suffering. While important, such an epistemological focus may fall prey to a charge of nostalgia, presupposing that Islamic traditions have a psychologized answer for a psychologized modernity ${ }^{4}$. This however maintains the paradigm of psychologization and the narrative that the individual qua individual can be distinguished and treated apart from the political conditions they inhabit. Moreover, the crux of the issue then is the following: This insistence on an Islamic psychology has the potential to play an integral (even if unintended) role in regulating an 'ideal Muslim' according to the nation-state, who now conforms to the status quo, albeit via a theocentric individualism.

Of course, all this raises more questions than it answers: Is it possible for Muslims to nurture individual, spiritual care, without reifying nationalism, neoliberalism or securitization? Can we reinvent a performance of 'resilience' (supposedly founded upon 'Islamic principles') that does not embolden contemporary policies of austerity? How do we escape the nationalist, securitizing gaze of psychology while still promoting mental health access and interventions among Muslim communities? I argue all such questions orbit around a troubling conundrum, which is not exclusive to Muslims: Can one truly maintain an apolitical stance toward the theory and practice of mental health?

Debates surrounding the ideological frameworks underlying the psy disciplines have long taken place (see Parker, 2015 for a recent overview); to be certain, these issues will not be answered in this article. The inevitability of the political nonetheless lends itself to the necessity of a decolonial — rather than simply Islamic - movement in MMH. Muslim mental health professionals do not simply face challenges of epistemology, they face the conditions of modernity itself. Such conditions extend beyond debates regarding psychology's Eurocentric foundations or the ability to translate traditional Islamic concepts for contemporary mental health concerns. In the remainder of this discussion, I argue that the performance of a decolonial Muslim mental health is constituted in two parts: A) as a practice that is in constant resistance with reigning ideological paradigms and industries, such as nationalism, neoliberalism, and securitization; and B) maintaining a philosophy of praxis—not simply epistemology—rooted in an Islamic paradigm of community for the suffering and the marginilized (Hallaq, 2019). Both of these parts will be discussed with practical recommendations moving forward.

\section{Beyond Islamicizing Psychology: A Resistance to Prevailing Paradigms}

One step toward a resistance towards prevailing paradigms, such as nationalism and capitalism, is a recognition one can never 'overcome' either. Mental health interventions from and for Western Muslims will inescapably operate within the confines of a liberal-capitalist nationstate. This however does not prevent the potential of developing a counter-hegemonic terrain

4. For a discussion on modernity as a post-traditional world whose institutions are built around risk/uncertainty, see Giddens (1991). 
"that endeavors to delink from the theoretical tenets and conceptual instruments of Western thought"(Mignolo, 2018, p. 7). There are three observations in this regard for MMH. First, there is a need to avoid Eurocentric, positivist discourses which erase the political categorization of being Muslim in the West, viewing it as another 'ethnic/religious identity.' In other words, when we speak of the racialization of Muslims, we are relating to mainstream systems of power which benefit from the continuous vilification of Muslims (Massoumi et al., 2017). Second, there is a need to educate $\mathrm{MMH}$ professionals in the history and sociology of mental health and develop more criticality on the science of the psy disciplines as Western artifacts. Third, there is a need to expand the purview of MMH beyond the psy disciplines for only a truly interdisciplinary outlook can capture the complexity of issues affecting Muslims. These three observations will be juxtaposed upon with the counterexample of 'cultural competence'.

One of the contemporary solutions to the issue of diversity is cultural competence (and its various iterations of diversity training). There is no agreed-upon definition of cultural competence-and its practices are diverse-but the intent remains the same: "to make health care services more accessible, acceptable, and effective for people from diverse ethnocultural communities" (Kirmayer, 2012, p. 151). The principle behind this strategy is intercultural sensitivity and understanding, a position espoused by national mental health strategies as well as Muslim practitioners. For example, Kaplick and Skinner (2017, p. 202) argue that an "inclusion of Islamic and other perspectives on human nature will also increase the understanding of cultural differences." However, given our discussion on the political, I question if cultural competence and intercultural awareness are truly panaceas to the wider challenges that globalization (and therefore diversity) poses to mental health. This is not to discredit efforts to sensitize professionals to Islam and Muslims, as this certainly is important. Rather, I would argue that cultural competence is an apolitical recapitulation of contemporary paradigms, which does not sufficiently evaluate the practice of mental health within a political and moral world. It thus serves to reify the status quo.

There is a need then to rethink how to make bare the ideological foundations underlying the practice of MMH today. To this, structural competence has been raised as a counter model (Metzl et al.,2018). Metzl and colleagues (2018) suggest that structural competence turns the gaze back toward us to understand how and why health structures perpetuate racial disparities, as opposed to cultural competence which keeps the gaze on the Others entering Eurocentric paradigms. They describe a degree at Vanderbilt University called Medicine, Health, and Society (MHS) which provides students with a foundation to "think critically about how complex social issues impact health, health care, and health policy" (Metzl et al., 2018, p. 191). In their study, Metzl and colleagues compared students in MHS major and pre-med science majors. They found that students who graduated from MHS had a significantly better understanding of how structural factors relate to issues of social, economic, and political structures impacting practice (e.g., racial disparities). This result however is accentuated by its juxtaposition with pre-med students, who equally believed in the importance of 'culture' in healthcare. In other words, while all students are convinced of the significance of 'culture', only those who underwent a tailored educational program understood its political complexity in healthcare. I argue such an educational plan (though limited in its own Eurocentric critique of itself) would be invaluable introduction for Muslim professionals entering the mental health industry; to look beyond 'Muslim' as another cultural identity and understand the particularities of being Muslim in Western nation-states.

Second, a truly decolonial movement in MMH cannot be confined to the psy disciplines. When it comes to issues of Muslim distress, the emphasis is found either in the fields of the psy disciplines (psychologists, psychiatrists, etc.) or theology (Muslim scholars, imams, etc.). This however dismisses the sociological, historical, material, and political contingencies underlying 
Muslim suffering, and reifies a Eurocentric compartmentalization of knowledge. Moreover, it risks psychologizing very real social, economic, and political pressures marginalizing Muslims. Such pressures require immediate collective action, not simply recourse to mental health interventions once they occur. We can draw here again on the wisdom of Martín-Baró (1996), who argues for a truly liberation psychology which does not negate the reality of ideological structures (such as capitalism), but offers a way to work through them.

If the 'wellbeing' of Muslims is truly at stake, and a need for decoloniality is at hand, then indeed a non-compartmentalized, community-based interdisciplinary movement to the conditions facing Muslims is the only recourse. For the paradigms of capitalism, nationalism, and securitization to be resisted, they must explicitly and continuously be grasped. While this resistance is stated broadly for the sake of brevity, suffice to say that a wider program of political awareness building among Muslim mental health professionals is vital for the success of any movement (Chomsky, 2003).

\section{Beyond Mental health: An Ethical Praxis}

A decolonial approach to Muslim mental health requires, above all else, a framework that does not solely take recourse to either Islamicizing psychology or psychologizing Islam. That is to say, to simply rely on Islamic principles (writ large) of soul nurturance, self-healing, and metal health interventions is insufficient. The moment any alleged Islamic theory or practice enters the world, it is immediately absorbed by the political. An uncritical performance of MMH reifies the reality of the modern world, dealing with distress, illness, and vulnerability according to Islamic concepts, but not alleviating the conditions of modernity plaguing humanity, let alone Muslims. Instead, a decolonial approach must certainly address the conditions of Muslims with broader, ethical considerations.

Here the writings of the philosopher Taha Abdul-Rahman provide a conceptual guide. While Taha Abdul-Rahman does also offer his own 'psycho-spiritual' view, the focus here will remain on the philosophy of praxis (Hallaq, 2019). Praxis here can be understood as the performances which precede theoretical modeling (i.e., Islamic psychology), based on an ethical paradigm rooted in Islamic cosmology - an ethics which precedes epistemology. Taking with this philosophy of praxis, I will address two intertwining observations which performances of MMH must inevitably confront: the commodification and compartmentalization of suffering.

The heart of the first problem is unsurprising: Capitalism. Moving toward a decolonial MMH, there is a need to understand how suffering is commodified and serviced through current neoliberal arrangements. Muslim mental health practitioners are either in rivalry to win desirable positions in healthcare settings (especially as token minority staff) or find themselves in even more stringent competition to maintain a private practice alongside others. And while the argument can be made that there is no end to suffering-as-commodity, and so there is enough room for endless therapists, this reifies 'mental health' as a panacea to society's problems (Cloud, 1997). Furthermore, therapy as a class privilege continues while, in fact, large populations of Muslims consist of refugees and asylum seekers (Hackett, 2017). In other words, prospective Muslim patients must choose between long waiting times for increasingly short-term service provision in public mental health settings beset with Islamophobic policies (Younis \& Jadhav, 2020) or a growing private sector of Muslim mental health professionals who inevitably must charge clients to sustain a living.

The second problem has to do with compartmentalization, in which 'psychology' is isolated from other factors. As explained earlier, there is an inevitability in this separation, for it is now custom to psychologize social and political conditions unto the individual (in spite of rhetorical affirmations of a bio-psycho-social lens to illness). If one can overcome psychologization is beyond the scope of this article (see De Vos, 2012 for a discussion), but suffice to say that if a 
Western Muslim is in anguish, 'mental health' is increasingly both the language and the remedy. Psychologization thus necessarily aids the evasion of social/political issues, even if these are often rhetorically acknowledged in passing. In $\mathrm{MMH}$, the added emphasis on spirituality in $\mathrm{MMH}$ does not adequately engage with the process of psychologization, nor does it necessarily capture the complexity of Western Muslim conditions.

A decolonial praxis has to begin with the Community (ummab) at heart, not through the outlines of a profession (i.e. psychology) or paradigm (i.e. mental health). Suffering cannot be a commodity but a shared, ethical responsibility within the Muslim community. This shared responsibility operates under the condition, it does not rationalize distress as an individual qua individual problem (or family, etc.), but as part of a larger ethically informed system which situates Muslims within a larger, transdisciplinary whole. A Muslim client should never be 'treated' to be left to return to school or work, nor simply mentored how to live a spiritually meaningful life. Rather, they should ideally experience the Community as an unbordered, ethically binding net which absorbs its difficulties altogether. Those suffering also share a role and responsibility in this net, and their interaction within it cannot be reduced to 'service users'. All Muslims should necessarily experience the Community's performance of this praxis, whereby their complex needs are organically met in explicit opposition to nationalist, neoliberal, or securitizing paradigms. Herein I would argue Muslims can find sanctuary; respite from a hegemony which inadvertently sees productivity and national loyalty as contingent qualities to wellbeing.

\section{Conclusion}

In their literature review, Haque and colleagues (2016) provide recommendations for the next ten years of research in 'Islamic psychology', but notably overlook situating 'Islamic psychology' within our political moment. As Martín-Baró observed however, there is no doubt of the psy discipline's ability to serve power. There is thus a need to consider how an Islamic psychology can offer a vision which addresses the structural concerns for the Community and does not simply reproduce the power relations of the modern world. The purpose of this article is to encourage mental health professionals to think critically of the paradigms underlying contemporary mental health discourse especially as they relate to Muslims.

There is good reason to believe that Muslim mental health is going to see immense growth in the near future. Muslim mental health professionals must consider rendering the political visible if they truly seek to ameliorate the suffering of Muslims. While it is acknowledged we cannot simply reproduce Eurocentric models, the same must be said about the structures upon which these models were built. Muslim mental health professionals may be oblivious to how mental health discourse plays a role in modern projects of nationalism, capitalism, and securitization. With the rise of nationalism across the Global North, the impetus for Muslim mental health professionals to re-politicize their role and practice has never been greater.

\section{References}

Abbas, M.-S. (2018). Producing 'internal suspect bodies': Divisive effects of UK counter-terrorism measures on Muslim communities in Leeds and Bradford. British Journal of Sociology. https://doi. org/10.1111/1468-4446.12366

Adib-Moghaddam, A. (2017). Psycho-nationalism: Global Thought, Iranian Imaginations (pp. 1-19). Cambridge: Cambridge University Press. 
Ali-Faisal, S. F. (2020). Islamic anti-patriarchal liberation psychology: A framework to decolonize psychology for Muslims. Feminism E Psychology, 3O(3), 343-362. https://doi.org/10.1177/0959353520941350

Altalib, H. H., Elzamzamy, K., Fattah, M., Ali, S. S., \& Awaad, R. (2019). Mapping global Muslim mental health research: Analysis of trends in the English literature from 2000 to 2015. Global Mental Health, 6, e6. https://doi.org/10.1017/gmh.2019.3

Badri, M. (2016). Abu Zayd al-Balkhis Sustenance of the Soul: The Cognitive Behavior Therapy of a Ninth Century Physician. London: International Institute of Islamic Thought.

Barylo, W. (2016). Neo-liberal not-for-profits: The embracing of corporate culture by European Muslim charities. Journal of Muslim Minority Affairs, 36(3), 383-398. https://doi.org/10.1080/13602004. 2016.1216626

Bauman, Z. (2013). Liquid times: Living in an age of uncertainty. New Jersey: John Wiley \& Sons.

Bell, K., \& Green, J. (2016). On the perils of invoking neoliberalism in public health critique. Critical Public Health, 26(3), 239-243. https://doi.org/10.1080/09581596.2016.1144872

Bertho, A. (2018). The Age of Violence: The Crisis of Political Action and the End of Utopia. London: Verso.

Bhui, K. (2016). Flash, the emperor and policies without evidence: Counter-terrorism measures destined for failure and societally divisive. British Journal of Psychology Bulletin, 40(2), 82-84.

Bor, J., Venkataramani, A. S., Williams, D. R., \& Tsai, A. C. (2018). Police killings and their spillover effects on the mental health of black Americans: A population-based, quasi-experimental study. Lancet, 392(10144), 302-310. https://doi.org/10.1016/S0140-6736(18)31130-9

Bottrell, D. (2013). Responsibilised resilience? Reworking neoliberal social policy texts. $M / C$ Journal, 16(5). https://doi.org/10.5204/mcj.708

Bulhan, H. A. (2015). Stages of colonialism in Africa: From occupation of land to occupation of being. Journal of Social and Political Psychology, 3(1), 239-256. https://doi.org/10.5964/jspp.v3i1.143

Campbell, C., \& Burgess, R. (2012). The role of communities in advancing the goals of the movement for global mental health. Transcultural Psychiatry, 49(3-4), 379-395. https://doi.org/10.1177/ 1363461512454643

Cherney, A., \& Murphy, K. (2016). Being a 'suspect community' in a post 9/11 world - The impact of the war on terror on Muslim communities in Australia. Australian \& New Zealand Journal of Criminology, 49(4), 480-496. https://doi.org/10.1177/0004865815585392

Chomsky, N. (2003). Understanding Power: The Indispensable Chomsky (P. R. Mitchell \& J. Schoeffel, Eds.). New York City: Vintage.

Cloud, D. L. (1997). Control and Consolation in American Culture and Politics: Rhetoric of Therapy (First edition). Thousand Oaks: SAGE Publications, Inc.

Colucci, E., Minas, H., Szwarc, J., Guerra, C., \& Paxton, G. (2015). In or out? Barriers and facilitators to refugee-background young people accessing mental health services. Transcultural Psychiatry, 52(6), 766-790. https://doi.org/10.1177/1363461515571624

Cushman, P. (1996). Constructing the self, constructing America: A cultural history of psychotherapy. Boston: Da Capo Press.

Davies, W. (2016). The Happiness Industry: How the Government and Big Business Sold Us Well-Being (Reprint edition). London: Verso Books.

De Vos, J. (2012). Psychologisation in Times of Globalisation. London: Routledge. https://doi.org/10.4324/ 9780203115459 
Fekete, E. (2018). Europe's Fault Lines: Racism and the Rise of the Right. London: Verso.

Frances, A. (2013). Saving Normal: An Insider's Revolt against Out-of-Control Psychiatric Diagnosis, DSM-5, Big Pharma, and the Medicalization of Ordinary Life (Reprint edition). Glasgow: William Morrow.

Furedi, F. (2003). Therapy Culture: Cultivating Vulnerability in an Uncertain Age. London: Routledge.

Goldberg, D. T. (2008). The Threat of Race: Reflections on Racial Neoliberalism. Malden: Wiley.

Grierson, J. (2020, February 21). Revealed: How teachers could unwittingly trigger counter-terror inquiries. The Guardian. https://www.theguardian.com/uk-news/2020/feb/21/public-sectorteachers-doctors-prevent-inquiries-trigger-referrals

Hackett, C. (2017). 5 facts about the Muslim population in Europe. Pew Research Center. https://www. pewresearch.org/fact-tank/2017/11/29/5-facts-about-the-muslim-population-in-europe/

Hallaq, W. (2014). The Impossible State: Islam, Politics, and Modernity's Moral Predicament (Reprint edition). New York: Columbia University Press.

Hallaq, W. (2019). Reforming Modernity: Ethics and the Nerw Human in the Philosophy of Abdurrabman Taha. New York: Columbia University Press.

Hassani, A. (2020). Islamophobia in Denmark: National Report 2019. In E. Bayrakli \& F. Hafez (Eds.), European Islamophobia Report 2019. SETA.

Haque, A., Khan, F., Keshavarzi, H., \& Rothman, A. E. (2016). Integrating Islamic Traditions in Modern Psychology: Research Trends in Last Ten Years. Journal of Muslim Mental Health, 10(1). https://doi.org/10.3998/jmmh.10381607.0010.107

Heath-Kelly, C., \& Strausz, E. (2018). Counter-terrorism in the NHS: Evaluating Prevent Safeguarding Duty in the NHS. University of Warwick. https://warwick.ac.uk/fac/soc/pais/research/researchcentres/ irs/counterterrorisminthenhs/project_report_60pp.pdf

Jenkins, R. (2014). Social identity (4th ed.). London: Routledge.

Johnson, A., \& Fernandez, S. (2019, February 23). Where does Shamima Begum exist? Ceasefire Magazine. https://ceasefiremagazine.co.uk/shamima-begum-exist/

Joseph, J. (2018). Varieties of resilience: Studies in governmentality. Cambridge: Cambridge University Press.

Kaplick, P. M., \& Skinner, R. (2017). The Evolving Islam and Psychology Movement. European Psychologist, 22(3), 198-204. https://doi.org/10.1027/1016-9040/a000297

Khan, R. K. A.W. (2015). An interview with Professor Malik Badri about his contributions to the Islamisation of psychology. Intellectual Discourse, 23(1), 159-172. ProQuest Central.

Kirmayer, L. (2012). Rethinking cultural competence. Transcultural Psychiatry, 49(2), 149.

Klug, B. (2015). Fawlty Logic: The Cracks in Cameron's 2011 Munich Speech. ReOrient, 1(1), 61. https://doi.org/10.13169/reorient.1.1.0061

Knudsen, R. A. (2020). Between vulnerability and risk? Mental health in UK counter-terrorism. Behavioral Sciences of Terrorism and Political Aggression, 13(1), 43-61. https://doi.org/10.1080/ 19434472.2019.1703782

Kundnani, A. (2014). The Muslims are coming!: Islamophobia, extremism, and the domestic war on terror. London: Verso Books.

Kundnani, A. (2017). Islamophobia as Ideology of US Empire. In N. Massoumi, T. Mills, \& D. Miller (Eds.), What is Islamophobia? (pp. 35-48). Pluto Press; JSTOR. https://doi.org/10.2307/j. ctt1rfsndp. 8 
Lasch, C. (2018). The Culture of Narcissism: American Life in An Age of Diminishing Expectations. New York: W.W. Norton \& Company.

Long, W. (2014). Critical Reflections on the Islamicisation of Psychology. Revelation and Science, 04(01), 6 .

Martín-Baró, I. (1996). Writings for a Liberation Psychology (A. Aron \& S. Corne, Eds.). Cambridge: Harvard University Press.

Massoumi, N., Mills, T., \& Miller, D. (Eds.). (2017). What is Islamophobia?: Racism, Social Movements and the State. London: Pluto Press.

Mayor of London. (2017, December 20). Mayor unveils new plans for countering violent extremism in London. London City Hall. https://www.london.gov.uk//press-releases/mayoral/major-newprogramme

Metzl, J. (2011). The Protest Psychosis: How Schizophrenia Became a Black Disease (50486th edition). Boston: Beacon Press.

Metzl, J., Petty, J., \& Olowojoba, O. V. (2018). Using a structural competency framework to teach structural racism in pre-health education. Social Science E Medicine, 199, 189-201. https://doi. org/10.1016/j.socscimed.2017.06.029

Mignolo, W., \& Walsh, C. E. (2018). On decoloniality: Concepts, analytics, and praxis. Durham: Duke University Press.

Mir, G., Ghani, R., Meer, S., \& Hussain, G. (2019). Delivering a culturally adapted therapy for Muslim clients with depression. The Cognitive Behaviour Therapist, 12, e26. https://doi.org/10.1017/ S1754470X19000059

Mohammad, F. (2016). The Productive Muslim: Where Faith Meets Productivity. Swansea: Awakenings Publications.

Mohr, S. H. (2019). Liberation Psychology from an Islamic Perspective. Journal of Religion and Society, 21(22).

Nolan Jr, J. L. (1998). The Therapeutic State: Justifying Government at Century's End. New York City: NYU Press.

Norton, A. (2013). On the Muslim question. New Jersey: Princeton University Press.

Open Society Justice Initiative. (2016). Eroding Trust, The UK's Prevent Counter-Extremism Strategy in Health and Education. Nerw York: Open Society Foundations, 16-17.

Parker, I. (2007). Revolution in psychology: Alienation to emancipation. London: Pluto Press.

Parker, I. (Ed.). (2015). Handbook of Critical Psychology (1 edition). London: Routledge.

Rizq, R. (2017). 'Pre-crime', Prevent, and practices of exceptionalism: Psychotherapy and the new norm in the NHS. Psychodynamic Practice, 23(4), 336-356. https://doi.org/10.1080/14753634.2017.1365005

Rose, N. (1999). Governing the Soul: Shaping of the Private Self (2nd Revised edition edition). London: Free Association Books.

Rose, N. (2018). Our Psychiatric Future. Cambridge: Polity Press.

Saad-Filho, A., \& Johnston, D. (2005). Introduction. In A. Saad-Filho \& D. Johnston (Eds.), Neoliberalism (pp. 1-6). Pluto Press: London.

Sabir, R. (2017). Blurred lines and false dichotomies: Integrating counterinsurgency into the UK's domestic 'war on terror.' Critical Social Policy, 0261018316683471. 
Sayyid, S. (2014). Recalling the Caliphate: Decolonisation and World Order. London: Hurst.

Schmiedebach, H.-P., \& Priebe, S. (2004). Social Psychiatry in Germany in the Twentieth Century: Ideas and Models. Medical History, 48(4), 449-472. https://doi.org/10.1017/ S0025727300007961

Seedat, M. (2020). Signifying Islamic Psychology as a Paradigm: A Decolonial Move. European Psychologist, 1-11. https://doi.org/10.1027/1016-9040/a000408

Silke, A. (1998). Cheshire-cat logic: The recurring theme of terrorist abnormality in psychological research. Psychology, Crime E Law, 4(1), 51-69. https://doi.org/10.1080/10683169808401747

Skrentny, J. D. (2008). Culture and Race/Ethnicity: Bolder, Deeper, and Broader. The ANNALS of the American Academy of Political and Social Science, 619(1), 59-77. https://doi.org/10.1177/ 0002716208319761

Tomlinson, M. (2013). Global mental health: A sustainable post Millennium Development Goal? International Health, 5(1), 1-3. https://doi.org/10.1093/inthealth/iht001

Toscano, A. (2017). Fanaticism: On the Uses of an Idea. London: Verso.

Valluvan, S. (2019). The clamour of nationalism: Race and nation in twenty-first-century Britain. Manchester: Manchester University Press.

Versi, J. (2020, January 5). Denmark's "ghetto plan" and the communities it targets. https://www.aljazeera. $\mathrm{com} /$ indepth/features/denmark-ghetto-plan-communities-targets-200114061024599.html

World Health Organization. (2013). Mental Health Action Plan 2013-2020. WHO. https://www.who. int/mental_health/publications/action_plan/en/

Younis, T. (2020). The psychologisation of counter-extremism: Unpacking PREVENT. Race E Class, 030639682095105. https://doi.org/10.1177/0306396820951055

Younis, T., \& Hassan, G. (2017). Changing Identities: A Case Study of Western Muslim Converts Whose Conversion Revised Their Relationship to Their National Identity. Journal of Muslim Minority Affairs, 1-11. https://doi.org/10.1080/13602004.2017.1294377

Younis, T., \& Hassan, G. (2018a). Rethinking Western Muslim Identity with Social Representations. Papers on Social Representations, 27(2), 22.

Younis, T., \& Hassan, G. (2018b). Second-generation Western Muslims: A qualitative analysis of multiple social identities. Transcultural Psychiatry, 56(6), 1155-1169. https://doi.org/10.1177/ 1363461518804554

Younis, T., \& Jadhav, S. (2019). Keeping Our Mouths Shut: The Fear and Racialized Self-Censorship of British Healthcare Professionals in PREVENT Training. Culture, Medicine, and Psychiatry, 43(3), 404-424. https://doi.org/10.1007/s11013-019-09629-6

Younis, T. and Jadhav, S. (2020), Islamophobia in the National Health Service: an ethnography of institutional racism in PREVENT's counter-radicalisation policy. Sociology of Health and Illness, 42, 610-626. doi:10.1111/1467-9566.13047 